\title{
Garlic compounds selectively kill childhood pre-B acute lymphoblastic leukemia cells in vitro without reducing T-cell function: Potential therapeutic use in the treatment of ALL
}

\author{
Greg Hodge' \\ Stephen Davis ${ }^{2}$ \\ Michael Rice' \\ Heather Tapp' \\ Ben Saxon' \\ Tamas Revesz' \\ 'Haematology/Oncology Department, \\ Women's and Children's Hospital, \\ North Adelaide, Australia; \\ 2Department of Mycology, Women's \\ and Children's Hospital, North \\ Adelaide, Australia
}

\begin{abstract}
Drugs used for remission induction therapy for childhood precursor-B acute lymphoblastic leukemia (ALL) are nonselective for malignant cells. Several garlic compounds have been shown to induce apoptosis of cancer cells and to alter lymphocyte function. To investigate the effect of garlic on the apoptosis of ALL cells and lymphocyte immune function, cells from newly diagnosed childhood ALL patients were cultured with several commonly used chemotherapeutic agents and several garlic compounds. Apoptosis, lymphocyte proliferation and T-cell cytokine production were determined using multiparameter flow cytometry. At concentrations of garlic compounds that did not result in significant increases in Annexin V and 7-AAD staining of normal lymphocytes, there was a significant increase in apoptosis of ALL cells with no alteration of T-cell proliferation as determined by CD25/CD69 upregulation or interferon $\gamma$, interleukin-2 or tumor necrosis factor- $\alpha$ intracellular cytokine production. In contrast, the presence of chemotherapeutic agents resulted in nonselective increases in both lymphocyte and ALL apoptosis and a decrease in T-cell proliferation and cytokine production. In conclusion, we show selective apoptosis of malignant cells by garlic compounds that do not alter T-cell immune function and indicate the potential therapeutic benefit of garlic compounds in the treatment of childhood ALL.
\end{abstract}

Keywords: childhood precursor-B acute lymphoblastic leukemia, garlic, apoptosis, immune function, intracellular cytokines

Chemotherapeutic agents used in the treatment of childhood precursor-B acute lymphoblastic leukemia (ALL) have been shown to induce apoptosis of ALL cells in vitro (Rohnghe et al 2001), however, hese drugs also induce apoptosis of normal lymphocytes (Leussink et al 2001). Hence there is a need for therapeutic agents that selectively reduce tumour burden while maintaining viability and immune function of normal cells.

The role of dietary compounds such as garlic in cancer prevention and treatment has been widely studied and debated (Lamm and Riggs 2001). There is epidemiological evidence that oral consumption of garlic is effective in reducing the incidence of esophageal and gastric cancers (Takezaki et al 2001).

Ajoene, a garlic-derived compound, has recently been shown to inhibit proliferation and induce apoptosis of human leukemia cells and induce apoptosis in myeloblasts from a CML patient in blast crisis (Dirsch et al 1998).

Allitridium, another garlic-derived compound, has been used intravenously for over twenty years in China to successfully treat Cryptococcus neoformans and other systemic fungal infections (Davis et al 2003). 
The aim of this present study was to investigate the effect of garlic and two garlic compounds, ajoene and allitridium, compared with commonly used chemotherapeutic drugs on apoptosis of ALL cells and normal lymphocytes in vitro from newly diagnosed ALL patients.

As garlic compounds have been shown to stimulate immune effector cells (Lamm and Riggs 2001) and modulate inflammatory cytokine production (Hodge et al 2002), the effect of garlic compounds and commonly used chemotherapeutic drugs on T-cell function following in vitro culture was also investigated.

\section{Patients and methods}

\section{Patient samples}

Blood and bone marrow samples were collected into preservative-free heparin from fifteen children presenting with pre-B ALL at the Women's and Children's Hospital, Adelaide and 12 age-matched volunteers. Mononuclear cells were isolated by standard density gradient centrifugation and cells resuspended in culture medium consisting of RPMI 1640 with $2 \times 10^{3} \mu \mathrm{mol} / \mathrm{L}$ L-glutamine (GibcoBRL, Sydney, Australia) supplemented with $10 \%$ fetal calf serum (FCS; CSL, Sydney, Australia), $100 \mathrm{IU} / \mathrm{mL}$ penicillin, $100 \mu \mathrm{g} / \mathrm{mL}$ streptomycin (Gibco BRL) (used for all experiments).

These mononuclear cells were used in all subsequent experiments.

\section{Garlic extract}

Fresh garlic extract was prepared as previously reported (Davis et al 2003). Garlic extract, Allitridium (Harvest Pharmaceutical Company, Shanghai, China), Ajoene (R.A.C., Venezuela) were diluted to desired protein concentration using culture medium immediately before use. Garlic compounds were used in a range of concentrations in experiments: ajoene $(0.0005,0.005,0.01,0.5,5 \mu \mathrm{g} / \mathrm{mL})$; allitridium $(0.0002,0.005,0.02,0.2,2.5 \mu \mathrm{g} / \mathrm{mL})$; garlic extract $(0.001$, $0.01,0.1,1,10 \mu \mathrm{g} / \mathrm{mL}$ protein).

\section{Chemotherapeutic drugs}

Chemotherapeutic drugs commonly used in the treatment of childhood ALL were also diluted with culture medium immediately before use in experiments to a range of concentrations likely achievable in vivo (Holleman et al 2003). Prednisolone $(0.08,0.8,8,80,250 \mu \mathrm{g} / \mathrm{mL}$ ) (Pharmacia and Upjohn, Sydney, Australia); L-asparaginase (0.003, 0.03, 0.3, 3, $10 \mu \mathrm{g} / \mathrm{mL}$ ) (Kyowa Hakko Kogyo, Tokyo, Japan); vincritine $(0.005,0.05,0.5,5,50 \mu \mathrm{g} / \mathrm{mL})$ (Mayne Pharma,
Mulgrave, Vic, Australia); daunorubicin (0.002, 0.02, 0.2, 2.0, $20 \mu \mathrm{g} / \mathrm{mL}$ ) (DBL, Sydney, Australia).

\section{Cell culture assays with drugs for apoptosis measurement}

Sensitivity of cells to several garlic compounds and several drugs commonly used in the treatment of childhood were tested by adding $80 \mu \mathrm{L}$ aliquots of cell suspension $\left(2 \times 10^{6}\right.$ cells $/ \mathrm{mL}$ ) PBMC and/or BMMC to $20 \mu \mathrm{L}$ of various concentrations of drugs in triplicate round-bottomed 96-well microculture plates. Cultures were incubated in a humidified $5 \% \mathrm{CO}_{2} / 95 \%$ air atmosphere at $37^{\circ} \mathrm{C}$. At 24,48 , and $72 \mathrm{hrs,}$ cells were resuspended and $100 \mu \mathrm{L}$ aliquots removed and stained with Annexin V FITC and 7-amino-actinomycin D (7-AAD) (Sigma, Sydney, Australia) as previously reported (Hodge et al 2005a) and analyzed using a FACSCalibur flow cytometer using CELLQUEST software (BD).

\section{Cell culture assays with drugs for T-cell activation}

The effect of garlic compounds and drugs used in the treatment of childhood ALL on normal T-cell activation was determined by incubating these compounds with the purified cells for $1 \mathrm{hr}$ in a humidified $5 \% \mathrm{CO}_{2} / 95 \%$ air atmosphere at $37^{\circ} \mathrm{C}$. Phytohaemmagglutinin $(10 \mu \mathrm{g})$ (Sigma) was then added to these cell cultures and plates reincubated in a humidified $5 \% \mathrm{CO}_{2} / 95 \%$ air atmosphere at $37{ }^{\circ} \mathrm{C}$. At $24 \mathrm{hrs}$, cell cultures were resuspended and $100 \mu \mathrm{L}$ aliquots removed and stained with $5 \mu \mathrm{L}$ of CD25 FITC (BD), CD69 PE (BD) and CD3 PC5 (Beckman Coulter) as previously reported (Hodge et al 2001).

\section{Cell culture assays with drugs} for intracellular T-cell cytokine production The effect of garlic compounds and drugs used in the treatment of childhood ALL on T-cell cytokine production was determined by incubating these compounds with the purified cells (prepared as for the apoptosis experiments above) for $4 \mathrm{hrs}$ and plates incubated at room temperature for $4 \mathrm{hrs}$. Cells were stimulated and intracellular cytokine production performed as previously reported (Hodge et al 2005b).

\section{Results}

\section{Effect of drugs on ALL and lymphocyte apoptosis}

Annexin V staining of normal lymphocytes from healthy controls and blasts and lymphocytes from ALL patients following 24 hrs culture is shown in Table 1. 
Table I The percentage of Annexin $\mathrm{V}$ positive and 7-AAD positive CD3+ lymphocytes and acute lymphoblastic leukemia cells following culture in the presence of no drugs (Control), $2 \mu \mathrm{g} / \mathrm{mL}$ daunorubicin, $50 \mu \mathrm{g} / \mathrm{mL}$ vincristine, $10 \mathrm{IU} / \mathrm{mL} \mathrm{L}$-asparaginase, $250 \mu \mathrm{g} / \mathrm{mL}$ prednisolone, $0.1 \mu \mathrm{g} / \mathrm{mL}$ garlic extract, $0.01 \mu \mathrm{g} / \mathrm{mL}$ ajoene, $0.005 \mu \mathrm{g} / \mathrm{mL}$ allitridium compared with normal healthy control subjects

\begin{tabular}{|c|c|c|c|c|c|c|c|c|c|c|c|c|c|}
\hline & \multicolumn{6}{|c|}{ CD3+ Lymphocytes } & \multicolumn{7}{|c|}{ Leukemia cells } \\
\hline & AnnV & Cp & Gp & 7AAD & Cp & Gp & AnnV & Cp & Gp & 7AAD & Cp & Gp & $\bar{n}$ \\
\hline Normal & $2 \pm 2$ & & & $4 \pm 2$ & & & & & & & & & 12 \\
\hline Control & $2 \pm 2$ & & & $5 \pm 2$ & & & $28 \pm 16$ & & & $36 \pm 2$ & & & 15 \\
\hline Garlic & $2 \pm 2$ & & & $7 \pm 3$ & & & $100 \pm 6$ & 0.000 & & $100 \pm 4$ & 0.000 & & 15 \\
\hline Ajoene & $9 \pm 4$ & 0.030 & & $8 \pm 4$ & & & $100 \pm 3$ & 0.000 & & $100 \pm 5$ & 0.000 & & 15 \\
\hline Allitrid & $7 \pm 3$ & 0.042 & & $9 \pm 3$ & 0.047 & & $100 \pm 2$ & 0.000 & & $100 \pm 4$ & 0.000 & & 15 \\
\hline Daunorubicin & $40 \pm 11$ & 0.000 & 0.000 & $69 \pm 10$ & 0.000 & 0.000 & $96 \pm 11$ & 0.000 & & $99 \pm 4$ & 0.000 & & 15 \\
\hline Vincristine & $41 \pm 14$ & 0.000 & 0.000 & $48 \pm 9$ & 0.000 & 0.000 & $83 \pm 16$ & 0.000 & 0.048 & $98 \pm 6$ & 0.000 & & 15 \\
\hline L-asparaginase & $23 \pm 8$ & 0.000 & 0.023 & $29 \pm 11$ & 0.002 & 0.004 & $51 \pm 12$ & 0.011 & 0.004 & $68 \pm 13$ & 0.036 & 0.014 & 15 \\
\hline Prednisolone & $10 \pm 6$ & 0.031 & & $29 \pm 8$ & 0.001 & 0.002 & $41 \pm 9$ & 0.016 & 0.002 & $57 \pm 11$ & 0.048 & 0.000 & 15 \\
\hline
\end{tabular}

Abbreviations: Cp, significantly different compared with Control; Gp, significantly different compared with cells cultured in Garlic; $n$, number of independent experiments.

There was a dose-dependent increase in both Annexin $\mathrm{V}$ positive ALL cells and lymphocytes in the presence of all drugs ( $\mathrm{p}<0.05$ for all, Mann Whitney) except lymphocytes in the presence of garlic extract $(p=0.235)$ (Table 1) compared with control with no drug (dose dependent data not shown).

Following culture for $48 \mathrm{hrs}$, there was a significant increase in Annexin V/7AAD positive lymphocytes and ALL cells in the presence of all drugs compared with control $(\mathrm{p}<0.05)$ except lymphocytes in the presence of garlic extract $(p=0.489)$ and ajoene $(p=0.380)$ (Table 1). There was a significant increase in Annexin V/7AAD positive ALL cells in the presence of garlic compared with several drugs. Representative dot plots showing Annexin V FITC and 7-AAD staining of CD34 positive ALL cells and CD34 negative lymphocytes following culture in the presence of $0.1 \mu \mathrm{g} / \mathrm{mL}$ garlic extract for $48 \mathrm{hrs}$ are shown in Figure 1. Almost all CD34 positive ALL cells stain positively for both Annexin V FITC and 7-AAD but very few CD34 negative lymphocytes show signs of apoptosis.

\section{Effect of drugs on lymphocyte activation}

At concentrations of garlic compounds that resulted in significant apoptosis of ALL cells but not of T-cells as determined by Annexin $\mathrm{V}$ and 7-AAD staining, there was no significant change in CD25 and CD69 upregulation ( $\mathrm{p}>0.05)$ (Table 2). In the presence of most drugs, there was a dose-dependent inhibition in CD25 and CD69 upregulation $(\mathrm{p}<0.05)$ (dose-dependent data not shown). The inhibition of these cytokines was significantly greater in the presence of most drugs compared with garlic compounds. Representative dot plots showing CD25 FITC and CD69 PE staining of CD3 positive $\mathrm{T}$ cells in the presence of $0.1 \mu \mathrm{g} / \mathrm{mL}$ garlic extract and $2 \mu \mathrm{g} / \mathrm{mL}$ daunorubicin, compared with control without drugs following culture with $10 \mu \mathrm{g} / \mathrm{mL}$ PHA for $24 \mathrm{hrs}$ are shown in Figure 2. There was a significant decrease in both CD25 and CD69 in the presence of daunorubicin ( $p<0.05)$ but not garlic extract compared with control with no drugs.

\section{Effect of drugs on lymphocyte cytokine production}

At concentrations of garlic compounds that resulted in significant apoptosis of ALL cells but not of T-cells as determined by Annexin V and 7-AAD staining, there was no significant change in intracellular interferon $\gamma(\mathrm{IFN} \gamma)$, interleukin-2 (IL-2), or tumor necrosis factor- $\alpha$ (TNF $\alpha$ ) production (Table 3 ). In the presence of most drugs, there was a dose-dependent inhibition in intracellular IFN $\gamma$, IL-2, TNF $\alpha$ production $(p<0.05)$. The dose-dependent inhibition of IFN $\gamma$ by drugs is shown in Figure 3 (dose-dependent data for IL-2 and TNF $\alpha$ not shown). The inhibition of these cytokines was significantly greater in the presence of most drugs compared with garlic compounds. Representative dot plots showing intracellular CD8+ and CD8- (CD4+) T-cell production of IFN $\gamma$, IL-2 and TNF $\alpha$ in the presence of 0.1 $\mu \mathrm{g} / \mathrm{mL}$ garlic extract and $50 \mu \mathrm{g} / \mathrm{mL}$ vincristine from PBMC from a patient with ALL compared with an aged-matched control with no drugs is shown in Figure 4. The percentage and mean fluorescence intensity of CD8+ and CD8- (CD4+) T-cells producing IFN $\gamma$, IL-2, and TNF $\alpha$ was significantly inhibited $(p<0.05)$ in the presence of vincristine but not garlic extract $(\mathrm{p}>0.05)$ compared with control without drugs (data not shown). Intracellular CD8+ and CD8- (CD4+) T-cell production of IFN $\gamma$, IL-2, and TNF $\alpha$ by PBMC from 


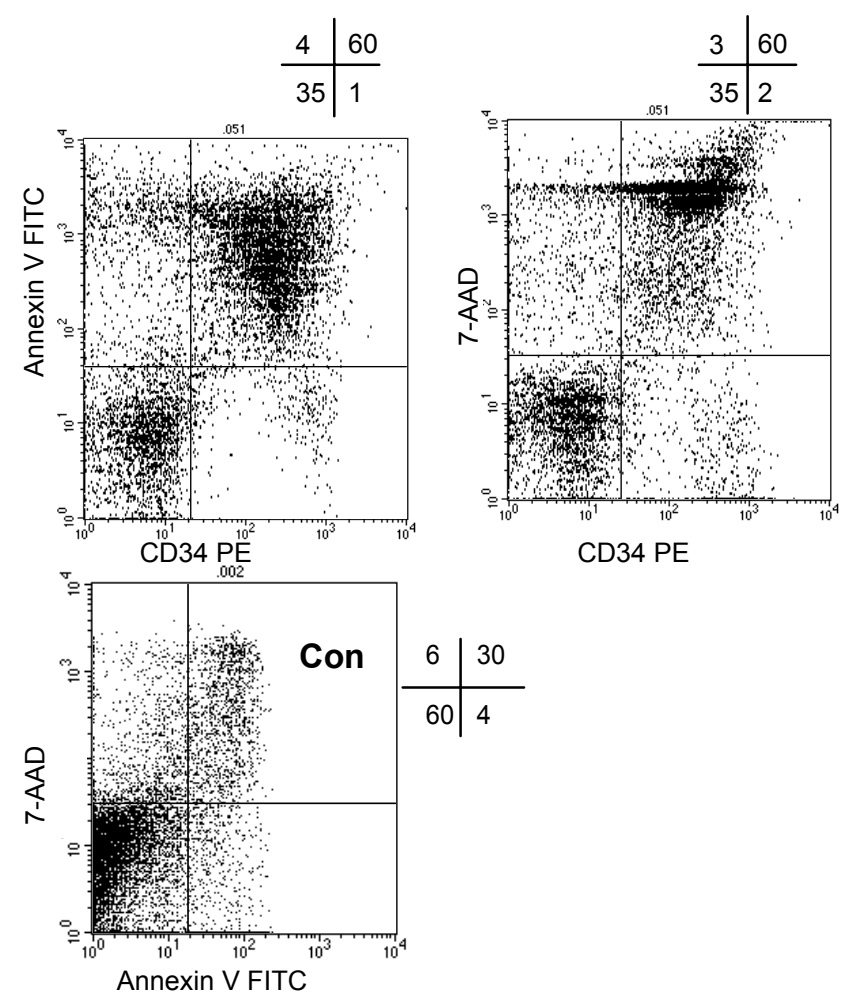

Figure I Representative dot plots showing Annexin V FITC and 7-AAD staining of CD34 positive ALL cells and CD34 negative lymphocytes following culture in the presence of $0.1 \mu \mathrm{g} / \mathrm{mL}$ garlic extract for $48 \mathrm{hrs}$ compared with control (Con) (no drug) (gated on CD34 positive ALL cells). Almost all CD34 positive ALL cells stain positively for both Annexin V FITC and 7-AAD in the presence of $0.1 \mu \mathrm{g} / \mathrm{mL}$ garlic extract but very few CD34 negative lymphocytes show signs of apoptosis.

the ALL patient was significantly decreased $(\mathrm{p}<0.05)$ compared with the healthy age-matched control.

\section{Discussion}

We report selective apoptosis of malignant cells by garlic compounds that do not alter lymphocyte viability or T-cell immune function in vitro. Drugs used for remission induction therapy for childhood pre-B ALL have been shown to be nonselective in targeting only malignant cells and result in loss of hemopoietic cells (Leussink et al 2001) and our current studies confirm these findings.

Our findings regarding the apoptotic effect of currently used chemotherapeutic drugs on childhood pre-B ALL cells are consistent with a recent report (Holleman et al 2003). We now show that the presence of these drugs result in a rapid transition of CD34 positive ALL cells from early (Annexin $\mathrm{V}+/ 7 \mathrm{AAD}-$ ) to late apoptosis (Annexin V+/7AAD+).

However, there have been reports of $\mathrm{CD} 34$ negative leukemic stem cells being resistant to current therapeutic strategies and that subsequent relapses may arise from this population (Cox and Blair 2005). Further studies into the effect of garlic compounds and current chemotherapeutic drugs on this small leukemic stem cell population are required once more precise definition of this subset is available.
T-helper-type 1 (Th1) responses are important in immune response against malignant cells, viruses and microbial infections. T-cell immune function has been shown to be impaired in children with ALL before and during treatment (Nash et al 1993). A previous study showed that intracellular

Table 2 The percentage of CD25 positive, CD69 positive, CD3 positive lymphocytes (mean $\pm s d$ ) following culture in the presence of no drugs (Control), $2 \mu \mathrm{g} / \mathrm{mL}$ daunorubicin, $50 \mu \mathrm{g} / \mathrm{mL}$ vincristine, $10 \mathrm{IU} / \mathrm{mL}$ L-asparaginase, $250 \mu \mathrm{g} / \mathrm{mL}$ prednisolone, $0.1 \mu \mathrm{g} / \mathrm{mL}$ garlic extract, $0.01 \mu \mathrm{g} / \mathrm{mL}$ ajoene, $0.005 \mu \mathrm{g} / \mathrm{mL}$ allitridium compared with normal healthy control subjects

\begin{tabular}{llllllll}
\hline \multicolumn{7}{c}{ CD3+ Lymphocytes } \\
\cline { 2 - 7 } & CD25 & Cp & Gp & CD69 & Cp & Gp & $\mathbf{n}$ \\
\hline Normal & $85 \pm 8$ & & & $98 \pm 12$ & & & 12 \\
Control & $75 \pm 10 \#$ & & & $90 \pm 12$ & & & 15 \\
Garlic & $79 \pm 8$ & & & $91 \pm 14$ & & & 15 \\
Ajoene & $78 \pm 7$ & & & $89 \pm 13$ & & & 15 \\
Allitrid & $81 \pm 8$ & & & $90 \pm 14$ & & & 15 \\
Daunorubicin & $28 \pm 9$ & 0.000 & 0.000 & $24 \pm 17$ & 0.000 & 0.000 & 15 \\
Vincristine & $26 \pm 11$ & 0.000 & 0.000 & $25 \pm 15$ & 0.000 & 0.000 & 15 \\
L-asparaginase & $49 \pm 6$ & 0.000 & 0.000 & $56 \pm 11$ & 0.000 & 0.000 & 15 \\
Prednisolone & $52 \pm 6$ & 0.031 & 0.021 & $68 \pm 8$ & 0.009 & 0.009 & 15 \\
\hline
\end{tabular}

Abbreviations: \#, significantly different compared with Normal (P , 0.048); Cp, significantly different compared with Control; Gp, significantly different compared with cells cultured in Garlic; n, number of independent experiments. 

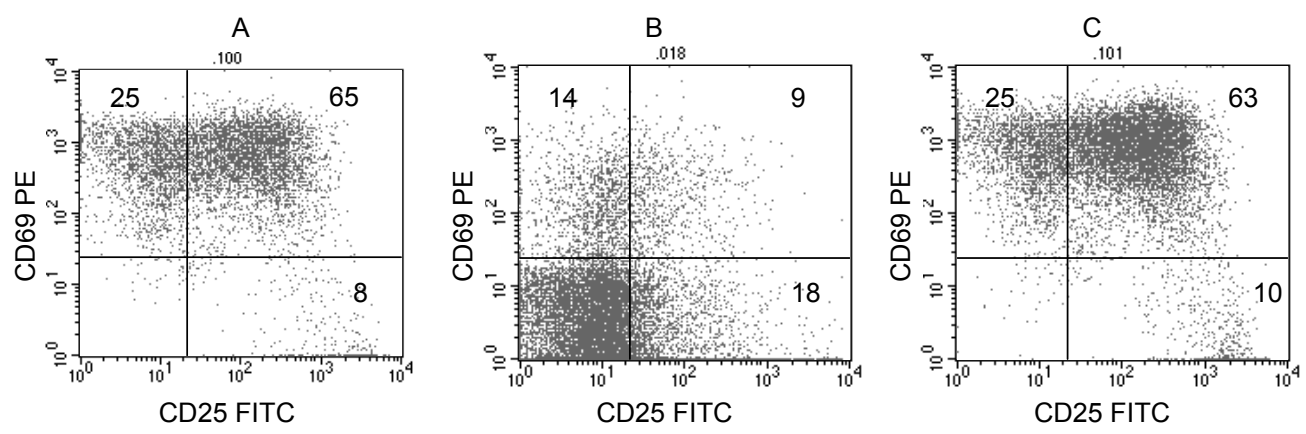

Figure 2 Representative dot plots showing CD25 FITC and CD69 PE staining of CD3 positive T cells in the presence of (A) $0.1 \mu g / \mathrm{mL}$ garlic extract and (B) $2 \mu \mathrm{g} / \mathrm{mL}$ daunorubicin, compared with (C) Control, following culture with $10 \mu \mathrm{g} / \mathrm{mL}$ PHA for $24 \mathrm{hrs}$. There was a significant decrease in both CD25 and CD69 in the presence of daunorubicin $(\mathrm{P}<0.05)$ but not garlic extract compared with control(C).

T-cell IFN $\gamma$ and IL-2 production was impaired in children with ALL (Nash et al 1993) and our current findings of reduced intracellular T-cell IFN $\gamma$ and IL-2 by the majority of these patients confirms these previous findings. Our additional findings of impaired T-cell TNF $\alpha$ production are important as TNF $\alpha$ has been shown to inhibit tumor cell growth in a variety of hematological malignancies (Reed and Pellechia 2005) and stimulate immune response to tumors (Vassalli 1992). Our current findings show that children with ALL have an impaired Th1 response at presentation and are subsequently treated with drugs that further impair the antileukemic immune response. Not surprisingly, we have previously shown that apoptotic cells have an impaired capacity for Th1 cytokine production (Hodge et al 2000). In contrast, the presence of garlic compounds did not impair $\mathrm{T}$-cell proliferation or Th1 responses by $\mathrm{T}$ cells from children with ALL or normal healthy controls.

Patients with childhood ALL are susceptible to a variety of bacterial, fungal, and viral infections. Garlic compounds have been shown to have antimicrobial properties in the prevention and treatment of common infective organisms in these patients such as methicillin-resistant Staphylococcus aureus (Cutler and Wilson 2004), Escherichia coli (Sasaki et al 1999), Aspergillus spp. (Shadkchan et al 2004), and invasive fungal infections (Davis 2005) and the mechanism of action of garlic has recently been described (Davis 2005). Garlic compounds have also been shown to be effective in the clinic against $\mathrm{CMV}$, a common pathogen isolated from these patients (Lu 1994). The intravenous use of garlic compounds in the treatment of invasive fungal infections in humans has been shown to be safe and effective (Davis 2003) and antifungal activity has been shown in human serum and urine after ingestion of garlic (Caporaso et al 1983) suggesting either form of therapy for the treatment of childhood ALL may be effective. Further investigations are warranted into the dose of garlic extracts, both oral and intravenous, required to achieve efficacy in the treatment of childhood ALL. After oral consumption or intravenous dose of garlic extracts to volunteers, serum from these volunteers could be substituted in similar experiments to that described in this manuscript

Table 3 The percentage of cytokine positive CD3 positive lymphocytes (mean \pm SD) following culture in the presence of no drugs (Control), $2 \mu \mathrm{g} / \mathrm{mL}$ daunorubicin, $50 \mu \mathrm{g} / \mathrm{mL}$ vincristine, $10 \mathrm{IU} / \mathrm{mL} \mathrm{L}$-asparaginase, $250 \mu \mathrm{g} / \mathrm{mL}$ prednisolone, $0.1 \mu \mathrm{g} / \mathrm{mL}$ garlic extract, $0.01 \mu \mathrm{g} / \mathrm{mL}$ ajoene, $0.005 \mu \mathrm{g} / \mathrm{mL}$ allitridium compared with control subjects $(\mathrm{n}=12)$

\begin{tabular}{|c|c|c|c|c|c|c|c|c|c|c|}
\hline & \multicolumn{10}{|c|}{ CD3+ Lymphocytes } \\
\hline & IFN $\gamma$ & Cp & Gp & IL-2 & Cp & Gp & TNF $\alpha$ & $\mathrm{Cp}$ & Gp & $\mathbf{n}$ \\
\hline Normal & $61 \pm 6$ & & & $4 I \pm 5$ & & & $45 \pm 8$ & & & 12 \\
\hline Control & $22 \pm 5 \#$ & & & $14 \pm 4 \#$ & & & $24 \pm 6 \#$ & & & 15 \\
\hline Garlic & $25 \pm 4$ & & & $17 \pm 5$ & & & $27 \pm 5$ & & & 15 \\
\hline Ajoene & $24 \pm 5$ & & & $16 \pm 3$ & & & $26 \pm 4$ & & & 15 \\
\hline Allitrid & $23 \pm 6$ & & & $15 \pm 6$ & & & $27 \pm 7$ & & & 15 \\
\hline Daunorubicin & $12 \pm 6$ & 0.037 & 0.031 & $2 \pm 2$ & 0.000 & 0.000 & $13 \pm 7$ & 0.031 & 0.026 & 15 \\
\hline Vincristine & $14 \pm 7$ & $0.04 I$ & 0.035 & $3 \pm 2$ & 0.000 & 0.000 & $16 \pm 8$ & 0.040 & 0.035 & 15 \\
\hline L-asparaginase & $18 \pm 8$ & & & $7 \pm 5$ & 0.033 & 0.025 & $19 \pm 6$ & 0.049 & 0.040 & 15 \\
\hline Prednisolone & $21 \pm 8$ & & & $10 \pm 5$ & & & $22 \pm 5$ & & & 15 \\
\hline
\end{tabular}

Abbreviations: \#, significantly different compared with Normal ( $p<0.000, p<0.000, p<0.003$ for IFNg, IL-2, and TNFa, respectively); Cp, significantly different compared with Control; Gp, significantly different compared with cells cultured in Garlic; n, number of independent experiments. 


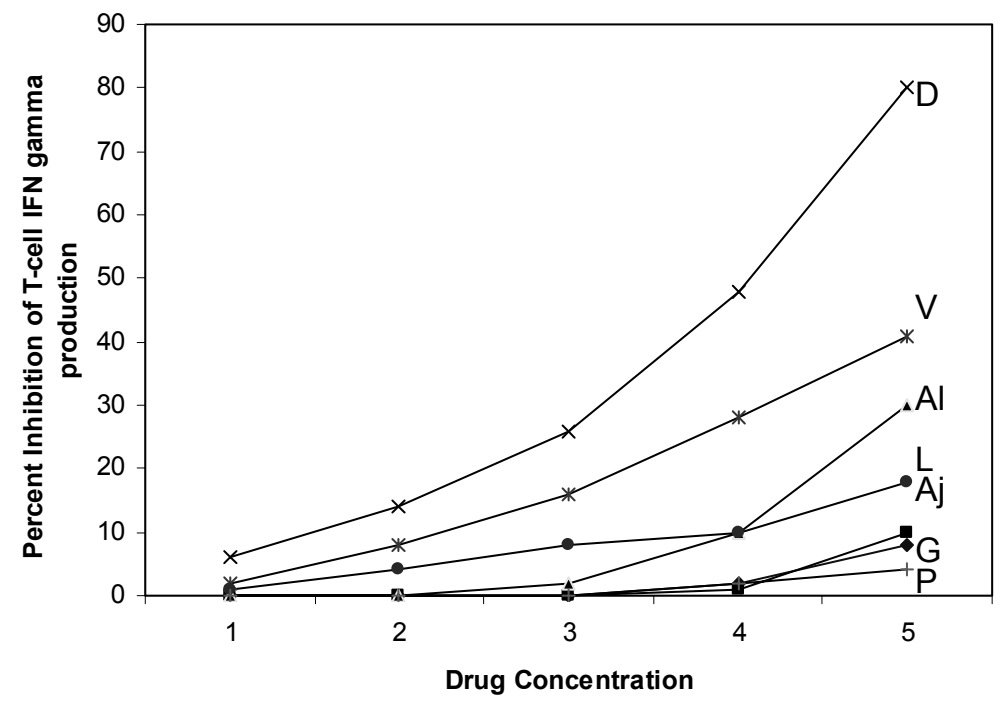

Figure 3 Graph showing dose-dependent inhibition of T-cell IFN $\gamma$ production in the presence of increasing concentrations of D: daunorubicin $(0.002,0.02,0.2,2.0,20 \mu g / \mathrm{mL})$, $\mathrm{V}$ : vincritine $(0.005,0.05,0.5,5,50 \mu \mathrm{g} / \mathrm{mL})$, Al: allitridium $(0.0002,0.005,0.02,0.2,2.5 \mu \mathrm{g} / \mathrm{mL}), \mathrm{L}: \mathrm{L}$-asparaginase $(0.003,0.03,0.3,3,10 \mu \mathrm{g} / \mathrm{mL}), \mathrm{Aj}$ : ajoene $(0.0005,0.005,0.01,0.5$, $5 \mu \mathrm{g} / \mathrm{mL})$, G: garlic extract $(0.001,0.01,0.1,1,10 \mu \mathrm{g} / \mathrm{mL})$ and P: Prednisolone $(0.08,0.8,8,80,250 \mu \mathrm{g} / \mathrm{mL})$.

A
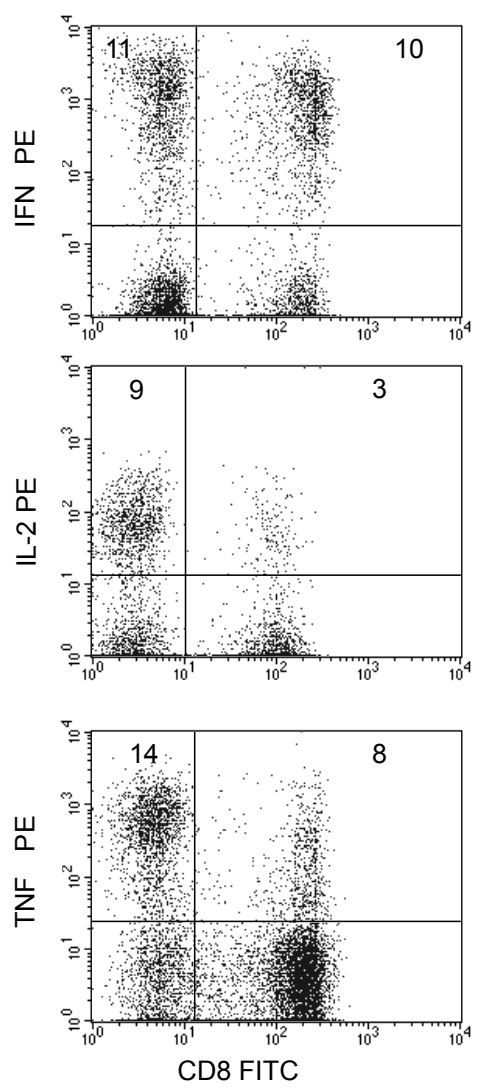

B
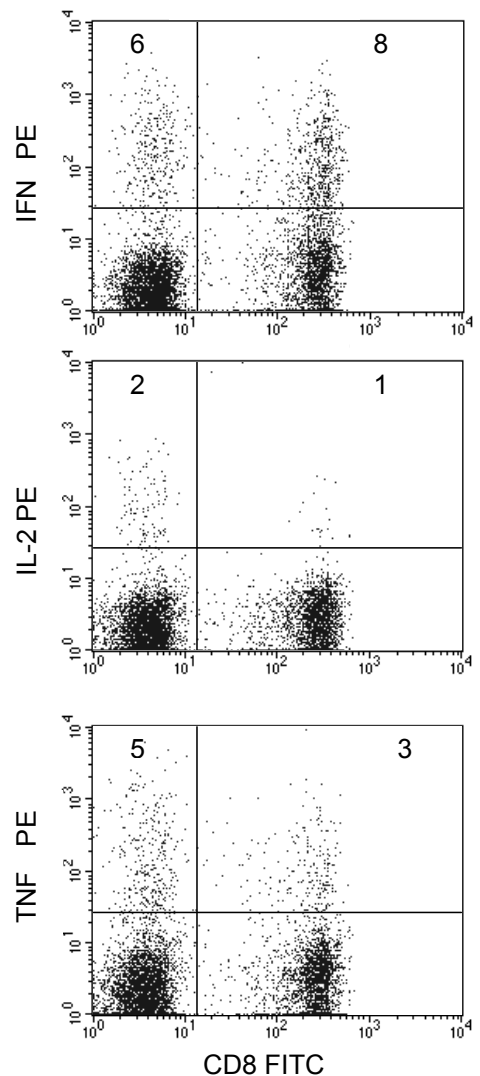

C
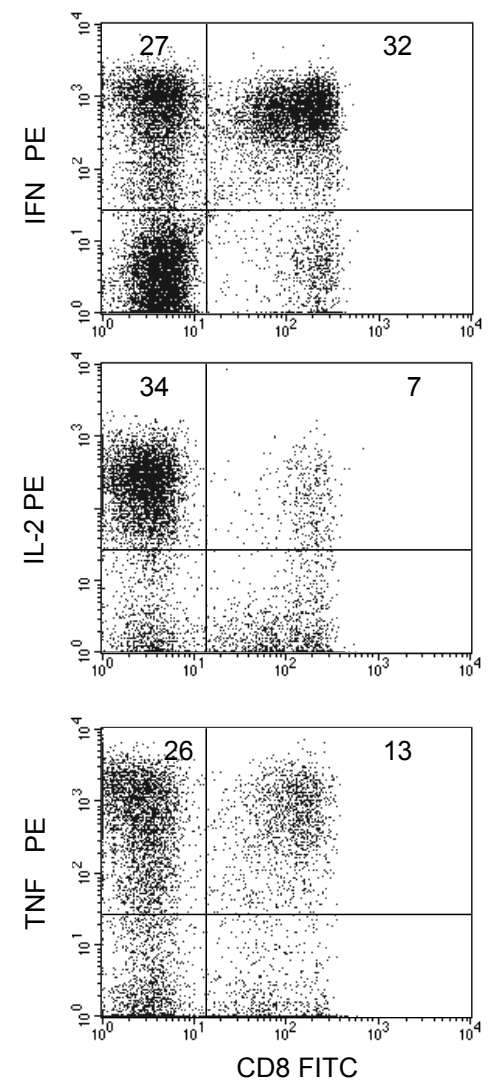

Figure 4 Representative dot plots showing intracellular CD8+ and CD8- (CD4+) T-cell production of IFN $\gamma$, IL-2 and TNF $\alpha$ in the presence of (A) $0.1 \mu g / m L$ garlic extract and (B) $50 \mu \mathrm{g} / \mathrm{mL}$ vincristine from PBMC from a patient with ALL compared with healthy aged-matched control subject (C). The percentage and mean fluorescence intenstiy of $C D 8+$ and CD8- (CD4+) T-cell producing IFN $\gamma$, IL-2, and TNF $\alpha$ was significantly inhibited $(p<0.05)$ in the presence of vincristine but not garlic extract $(p>0.05)$ compared with control without drugs (data not shown). Intracellular CD8+ and CD8- (CD4+) T-cell production of IFN $\gamma$, IL-2, and TNF $\alpha$ by PBMC from the ALL patient was significantly decreased $(p<0.05)$ compared with control. 
to determine optimal dosage to achieve maximal killing of ALL cells while maintaining Th1 response.

Previous findings taken together with our current investigations argue for the use of garlic compounds in the therapeutic treatment of childhood pre-B ALL to selectively kill ALL cells and prevent morbidity associated with pathogenic microbial organisms while maintaining cellular immune function.

\section{Acknowledgments}

This study was supported by a Channel 7 Foundation Research Grant. The authors report no conflicts of interest.

\section{References}

Cutler RR, Wilson P. 2004. Antibacterial activity of a new, stable, aqueous extract of allicin against methicillin-resistant Staphylococcus aureus. Br J Biomed Sci, 61:71-4.

Caporaso N, Smith S, Eng R. 1983. Antifungal activity in human serum and urine after ingestion of garlic (Allium sativum). Antimicrob Agents Chemother, 23:700-2.

Davis SR. 2005. An overview of the antifungal properties of allicin and its breakdown products- the possibility of a safe and effective antifungal prophylactic. Mycoses, 48:95-100.

Davis S, Perrie R, Apitz-Castro R. 2003. In vitro susceptibility of S. Prolificans to ajoene, allitridium and raw extract of garlic. J Antimicrob Chemother, 51:593-7.

Dirsch VM, Gerbes AL, Vollmar AM. 1998. Ajoene, a compound of garlic, induces apoptosis in human promyelocytic cells, accompanied by generation of reactive oxygen species and activation of nuclear factor kappaB. Mol Pharmacol, 53:402-7.

Hodge G, Han P. 2001. Effect of Factor VIII concentrate on lymphocyte proliferation and apoptosis: TGF $\beta$ is a significant immunomodulatory component of FVIII. Br J Haematol, 115:376-81.

Hodge G, Hodge S, Han P. 2002. Allium sativum (Garlic) suppresses leucocyte inflammatory cytokine production in vitro: potential therapeutic use in the treatment of inflammatory bowel disease. Cytometry, 48:209-15.
Hodge S, Hodge G, Holmes M, et al. 2005a. Increased apoptosis in the airways in COPD persists after smoking cessation. Eur Resp J, 25:447-54.

Hodge G, Hodge S, Reynolds P, et al. 2005b. Intracellular cytokines in blood $\mathrm{T}$ cells in lung transplant patients- a more relevant indicator of immunosuppression than drug levels. Clin Exper Immunol, 139:159-64.

Hodge G, Hodge S, Han P. 2000. Increased levels of apoptosis of leucocyte subsets in PBMCs compared to whole blood as shown by Annexin V binding- relevance to cytokine production. Cytokine, 12:1763-8.

Holleman A, den Boer ML, Kazemier KM, et al. 2003. Resistance to different classes of drugs is associated with impaired apoptosis in childhood acute lymphoblastic leukemia. Blood, 102:4541-6.

Lamm DL, Riggs DR. 2001. Enhanced immunocompetence by garlic: role in bladder cancer and other malignancies. J Nutr, 131:1067-70.

Leussink VI, Jung S, Merschdorf U, et al. 2001. High dose methylprednisolone therapy in multiple sclerosis induces apoptosis in peripheral blood leucocytes. Arch Neurol, 58:91-7.

Lu DP. 1994. Bone marrow transplantation in the Peoples Republic of China. Chinese Bone Transplant Registry, 13:703-4.

Nash KA, Mohammed G, Nandapalan N, et al. 1993. T cell function in children with acute lymphoblastc leukemia. Br J Haematol, 83:419-27.

Reed JC, Pellecchia M. 2005. Apoptosis-based therapies for haematological malignancies. Blood, 106:408-18.

Ronghe M, Burke GA, Lowis SP, et al. 2001. Remission induction therapy for childhood acute lymphoblastc leukemia: clinical and cellular pharmacology of vincristine, corticosteroids, L-asparaginase and anthracyclines. Cancer Treat Rev, 27:327-37.

Takezaki T, Gao CM, Wu JZ, et al. 2001. Dietary protective and risk factors for oesophageal and stomach cancers in a low epidemic area for stomach cancer in Jiangsu Province, China: comparison with those in a high epidemic area. Japan J Cancer Res, 92:1157-65.

Sasaki J, Kita T, Ishita K, et al. 1999. Antibacterial activity of garlic powder against Escherichia coli 0-157. J Nutr Vitaminol (Tokyo), 45:785-90.

Shadkchan Y, Shemesh E, Mirelman D, et al. 2004. Efficacy of allicin, the reactive molecule of garlic, in inhibiting Aspergillus spp. in vitro, and in a murine model of aspergillosis. J Antimicrob Chemother, 53:832-6.

Vassalli P. 1992. The pathophysiology of tumour necrosis factors. Ann Rev Immunol, 10:411-52. 
